\title{
Contribution to the hydrographical structure of the eastern German Bight
}

\author{
P. Martens \\ Biologische Anstalt Helgoland (Litoralstation); \\ D-2282 List/Sylt, Federal Republic of Germany
}

\begin{abstract}
Temperature, salinity, micronutrients, seston components and mesozooplankton were measured on a cruise in the eastern German Bight during November 1976. Three different water bodies and a mixing area which is divided into two subareas could be identified. The water masses differed significantly in regard to temperature, salinity, micronutrients and seston components. In some cases differences in the amounts of mesozooplankton could be found. Temperature and salinity of the water of the Elbe estuary and of the Wadden Sea were relatively low, but anounts of micronutrients and seston were high, whereas the water of the North Sea water body was of higher temperature and salinity with lower amounts of micronutrients and seston. The North Frisian coastal water and a southern mixing area can be regarded as mixing areas between these water bodies.
\end{abstract}

\section{INTRODUCTION}

According to Goedecke (1968) the eastern German Bight is a zone of intensive mixing of two water bodies, the North Sea water and the coastal water which is of lower salinity and density. In addition, the water of the river Elbe leads to a strong inhomogenity in this area which can be seen in the distribution of dead and living suspended particles and micronutrients. Investigations conducted by Goedecke (1968) on the hydrography of the German Bight from 1933 to 1967 and by Künne (1952) in 1948 and 1949 on the zooplankton lead to the conclusion that a formation of relatively stable water bodies takes place in the eastern German Bight. These water bodies differ not only in temperature and salinity but also in the amount of micronutrients, phyto- and zooplankton.

A series of cruises during different seasons was planned in order to investigate this area with respect to annual and seasonal changes. This paper describes the conditions found during the first cruise in November 1976.

\section{MATERIAL AND METHODS}

From November 15th to November 20th 1976 the following components were measured at 46 stations (position of the stations see Fig. 3): $\mathrm{PO}_{4}, \mathrm{SiO}_{3}, \mathrm{NO}_{3}, \mathrm{NO}_{2}$, 
$\mathrm{NH}_{4}$ (Autoanalyzer from deep frozen samples); chlorophyll (UNESCO standard method); total organic carbon = TOC (Menzel \& Vaccaro, 1964); particle concentration (Coulter Counter); mesozooplankton (vertical net hauls with $100 \mu \mathrm{m} \mathrm{Ap-}$ stein-net).

Temperature and salinity were measured at 113 stations including those stations mentioned above (Bathy-sond). Measurements were made by members of the Deutsches Hydrographisches Institut, Hamburg (Becker, unpublished data), micronutrients, chlorophyll and TOC by members of the Biologische Anstalt Helgoland (Hickel \& Weigel, unpublished data).

For determination of particle concentrations a Coulter Counter Model $\mathrm{Zb}$ was used with two different capillaries $(100 \mu \mathrm{m}$ and $560 \mu \mathrm{m})$ using two amplifications (1 and 16); thus particles from 5-12 $\mu \mathrm{m} \varnothing, 11-31 \mu \mathrm{m} \varnothing$ and $30-80 \mu \mathrm{m} \varnothing$ could be measured (Sheldon \& Parsons, 1967).

When using the $100 \mu \mathrm{m}$ Apstein-net small animals such as first naupliar stages of copepods and bigger animals such as medusae were not caught quantitatively. The animals were preserved in $4 \%$ formaldehyde solution and counted under the stereomicroscope. Copepodids and nauplii of Psendocalanus elongatus and Paracalanus parvus were not discerned. Also the first naupliar stages of Acartia sp. could not be separated from those of Eurytemora sp. with certainty.

By means of a temperature-salinity diagram (Fig. 1a, b) the stations were grouped into water bodies. A station was appointed to a water body when at least $70 \%$ of the water in the water column was of certain origin; e.g. a station with $71 \%$ of North Sea water was ascribed to the North Sea water body. A more detailed description of this technique is given by Becker (unpublished).

When the portion of the different water masses at one station was lower than $70 \%$ the station was assigned to a mixing area. In addition, the different water bodies were characterized by means of a temperature-particle diagram (Fig. 2) which leads to a better differentiation in some cases. In both cases the same water bodies could be found. The water bodies were tested for significant differences between all parameters investigated (Chi-square-test, analysis of variance, $\mathrm{H}$-tesr) (Sachs, 1974).

\section{RESULTS}

A statistical calculation of the parameters measured (Tables 1-3) revealed three different water bodies and a mixing area in the eastern German Bight. The water bodies differ significantly in many of the variables investigated. The mixing area can be divided into two subareas, a northern and a southern part which differ in some biological, physical and chemical properties. The following water masses can be identified:

(a) Water of the Elbe estuary, (b) water of the Wadden Sea, (c) water of the mixing area and (d) North Sea water.

The water of the Elbe estuary stretches as a narrow band up to the isle of Scharhörn. It is of relatively low salinity $(13.6-28.0 \%$ ) and low temperature $\left(7.2-7.6^{\circ} \mathrm{C}\right)$. The amount of micronutrients is relatively high compared with the 

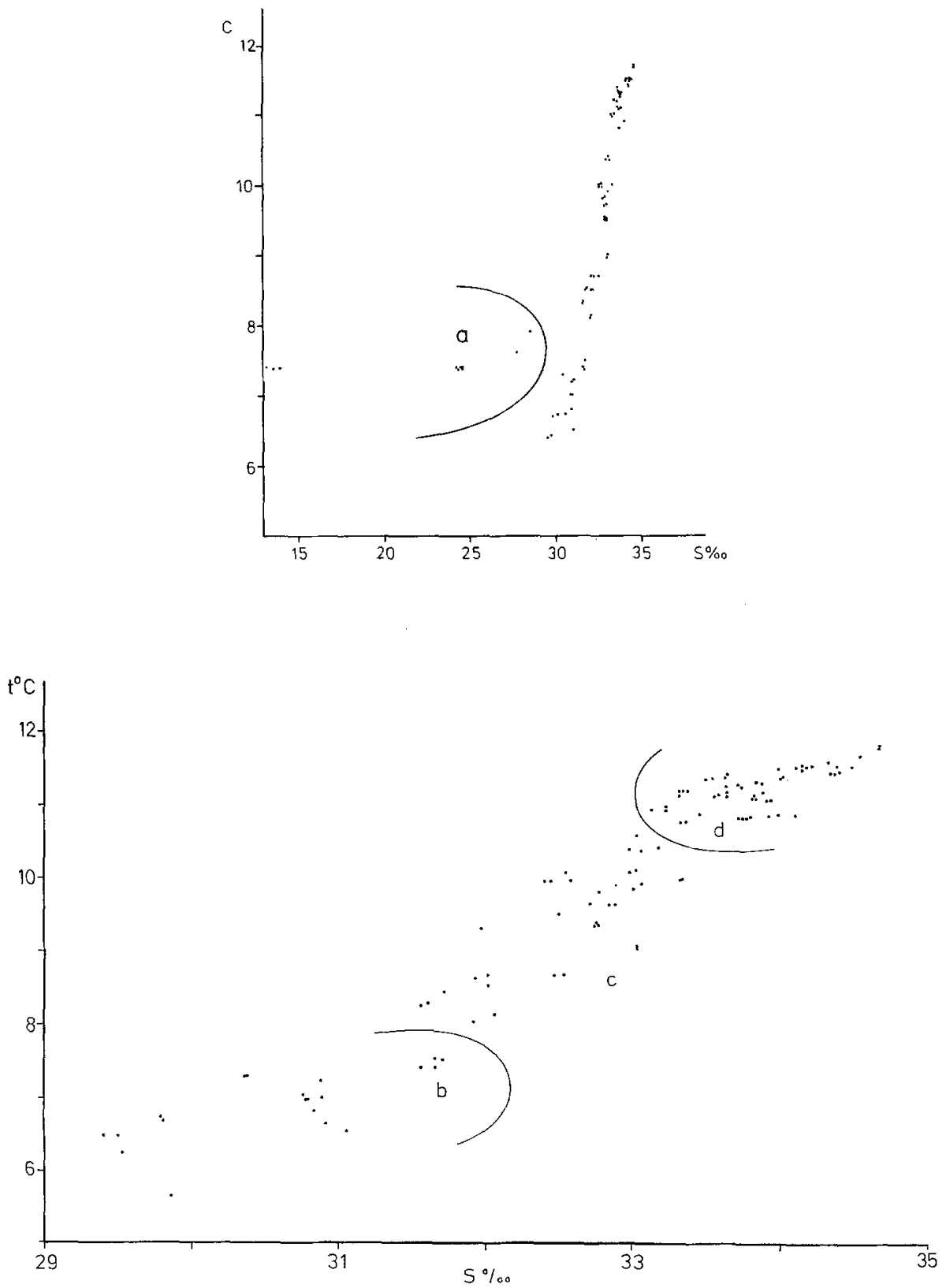

Fig. 1: Temperature-salinity diagram of the different water bodies and mixing areas in the eastern German Bight. Above: Whole salinity range, $a=$ water of the Elbe estuary. Below: Range 29 to $35 \%$ extended, $b=$ water of the Wadden Sea, $c=$ mixing area, $d=$ water of the North Sea 


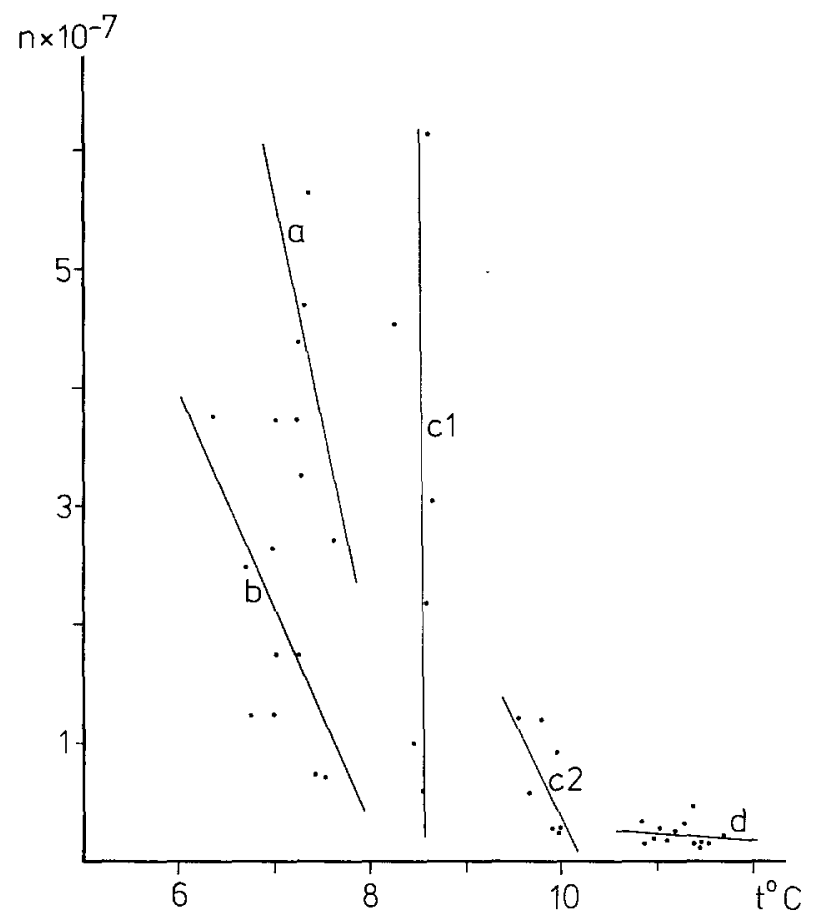

Fig. 2: Temperature-particle diagram (particles 5-12 $\mu \mathrm{m} \varnothing$ ) of the different water bodies and mixing areas in the eastern German Bight. $a=$ water of the Elbe esturay, $b=$ water of the Wadden Sea, $c 1=$ North Frisian coastal water, $c 2=$ southern mixing area, $\mathrm{d}=$ water of the North Sea

other water bodies. $\mathrm{PO}_{4}\left(2.0-5.6 \mu \mathrm{g}\right.$ at $\left.\mathrm{l}^{-1}\right)$ and $\mathrm{SiO}_{3}\left(16.0-30.4 \mu \mathrm{g}\right.$ at $\left.\mathrm{1}^{-1}\right)$ show highest values in this water body. The amount of seston measured as TOC, chlorophyll and particle concentration is also highest in the Elbe estuary. It is the only part of the area investigated where the copepod Eurytemora sp., which prefers brackish water, could be found. The great amounts of nauplii identified as Acartia sp. comprise the first naupliar stages of Eurytemora sp. which were not separated from the first naupliar stages of Acartia sp.

The water body of the Wadden Sea comprises the northern and southern Wadden Sea of Sylt and the North Frisian Wadden Sea (Fig. 3). It is an area of relatively low salinity $\left(29.5-31.7 \%\right.$ ) and low temperature $\left(5.6-7.5^{\circ} \mathrm{C}\right)$ with a high amount of micronutrients. Nitrogen components show a maximum $\left(\mathrm{NH}_{4}: 8.6-17.4\right.$ $\mu \mathrm{g}$ at $1^{-1}$ ). Phosphate and silicate concentrations are lower than in the Elbe estuary but higher than in the remaining water bodies. Biologically this water body is characterized by high numbers of larvae of Spionidae (150-3700 $\left.\mathrm{m}^{-3}\right)$ and Noctiluca miliaris (900-4700 $\mathrm{m}^{-3}$ ) (Figs 4, 5).

The mixing area of North Sea water, water of the Elbe estuary and of the Wadden Sea is made up of two subareas, the North Frisian coastal water and a southern mixing area (Fig. 3). The mean values of temperature and salinity are 


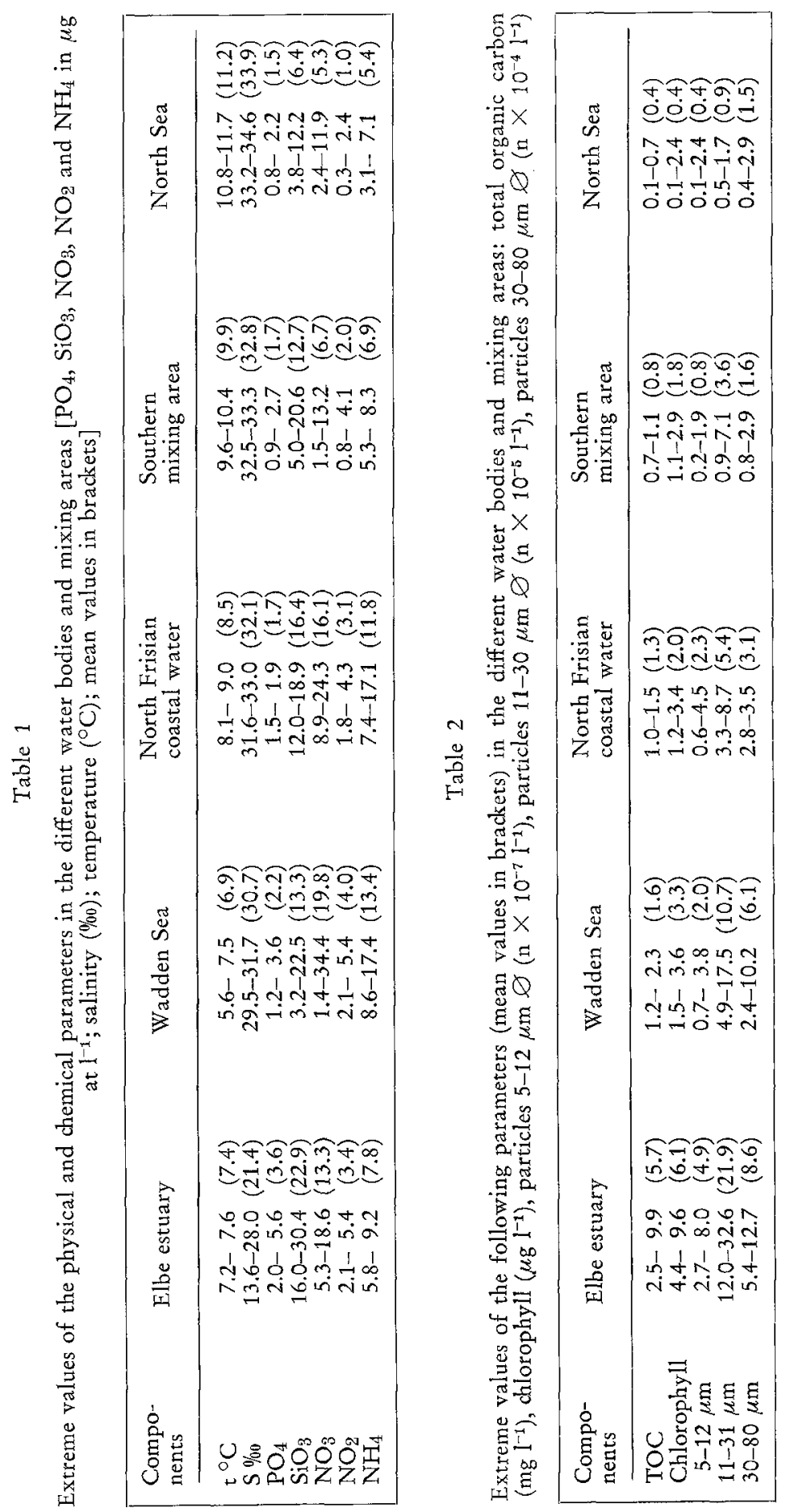


Contribution to the hydrographical structure

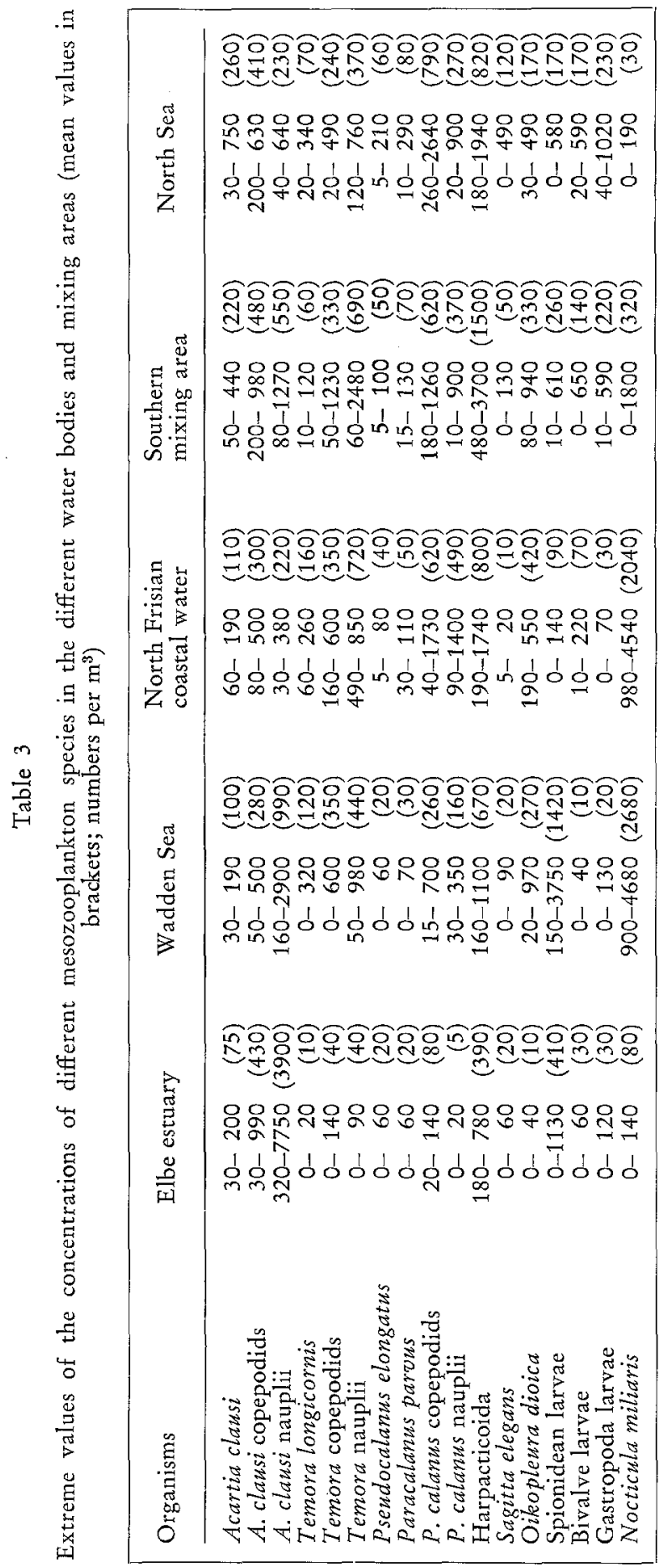



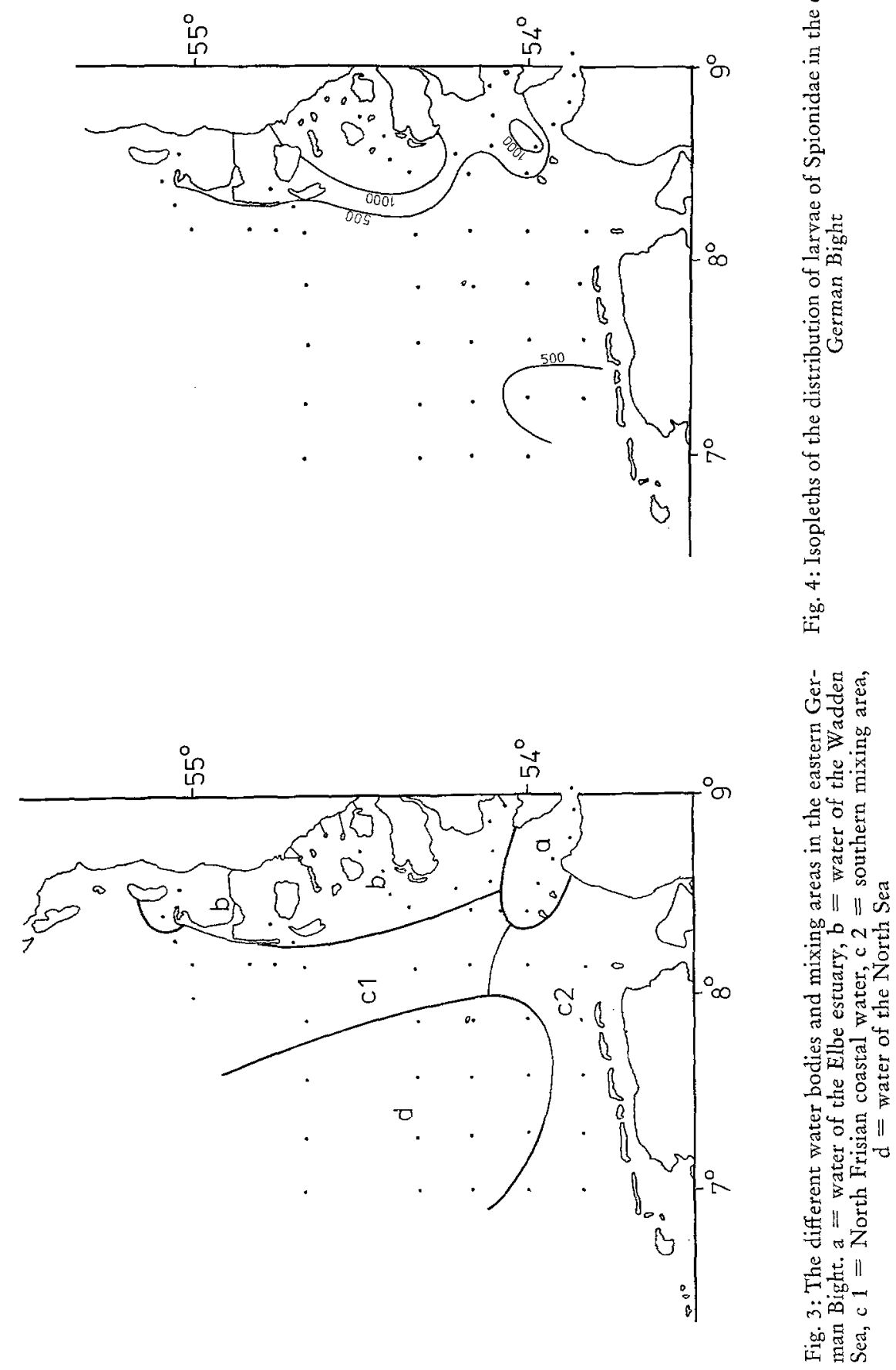

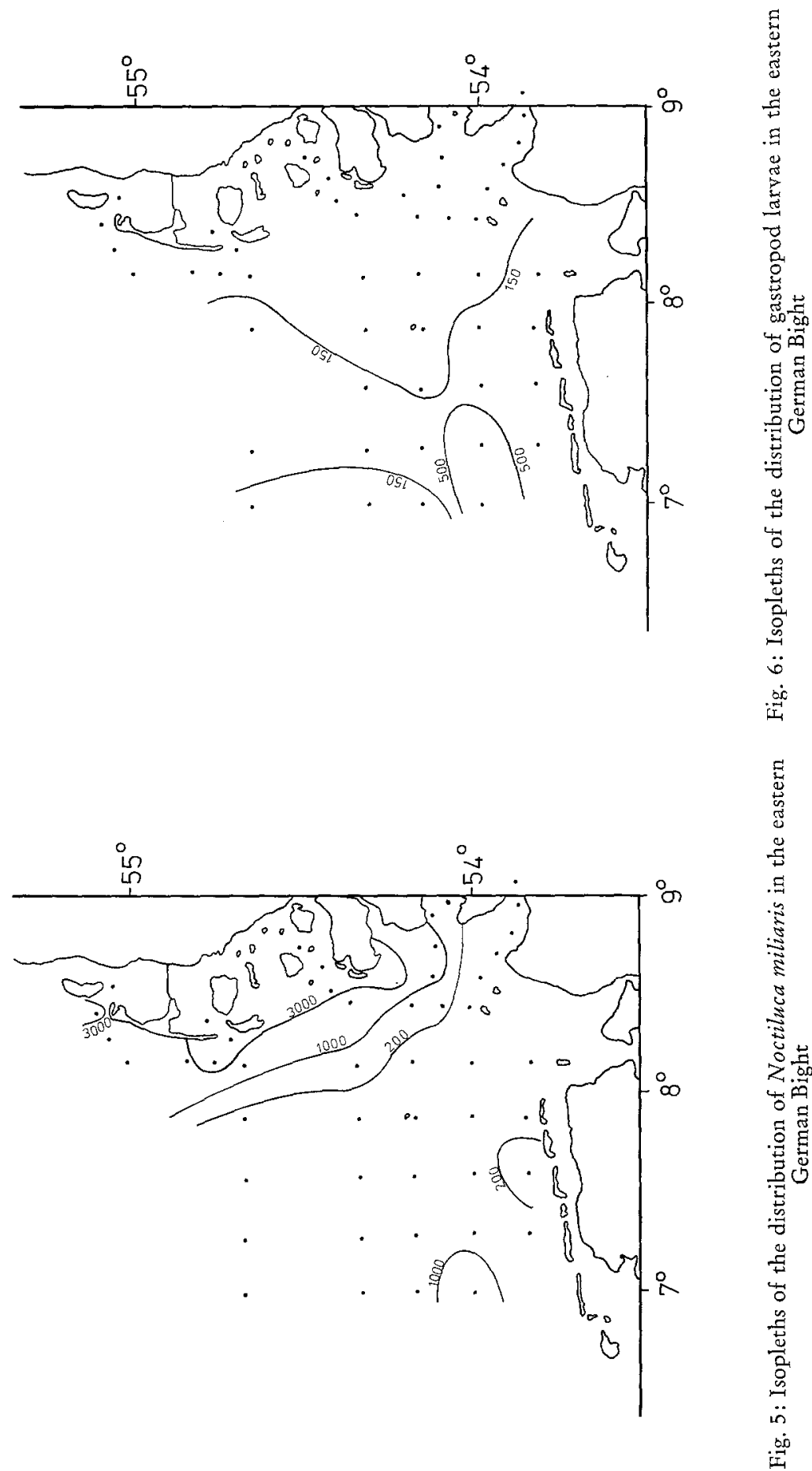
higher than in the Wadden sea $\left(31.6-33.3 \%\right.$ \% $\left.; 8.1-10.4^{\circ} \mathrm{C}\right)$ but lower than in the North Sea water. Concerning the chemical parameters, the water of the mixing area does not significantly differ from that of the Wadden Sea, but the concentrations are higher than in the North Sea water. In regard to the concentrations of TOC, chlorophyll and suspended particles this area of the German Bight also has an intermediate position between the water masses of the Elbe estuary and the North Sea.

Compared to the North Frisian coastal water the southern mixing area has a slightly higher salinity $(\triangle \mathrm{S} \%=0.7 \%)$ and a higher temperature $\left(\triangle \mathrm{t}{ }^{\circ} \mathrm{C}=\right.$ $1.4^{\circ} \mathrm{C}$ ). The main difference between these two subareas is of biological character. Whereas the North Frisian coastal water reveals high numbers of Noctiluca miliaris (1000-4500 $\mathrm{m}^{-3}$ ) which do not significantly differ from those of the Wadden Sea, in the southern mixing area relatively high concentrations of gastropod larvae $\left(10-600 \mathrm{~m}^{-3}\right.$ ) (Fig. 6) occur.

North Sea water comprises the area north west of the other water bodies, the western border not being included in this investigation (Fig. 3). Temperature $\left(10.8-11.7^{\circ} \mathrm{C}\right)$ and salinity $(33.2-34.6 \%$ ) reach maximum values. Silicate, nitrate and the amount of seston attain the lowest values of all water bodies (Tables 1-3). The amount of gastropod larvae does not significantly differ from that of the southern mixing area $\left(40-1000 \mathrm{~m}^{-3}\right)$.

\section{DISCUSSION}

Comparing position and numbers of the water bodies found during this investigation with those of previous studies (Künne, 1952; Goedecke, 1968) a high constancy over the relatively long study period (beginning of Goedecke's investigations in 1933) can be noted. Künne's results, which are based on the rather low number of 15 stations, did not reach the high resolution obtained from this examination or that of Goedecke; however he could demonstrate the existence of a coastal water body and also observed mixing areas.

Kalle (1937) characterizes a water body in the following way (translated from German): "A water body is a water mass which, because of its common origin or because of a constantly affecting source of energy, can be regarded as a clearly homogeneous unit. Such water bodies can be characterized by their uniform behaviour in regard to physical, chemical and biological characteristics."

In this investigation the constantly affecting source of energy is the collision of the denser North Sea water and the coastal water which is of lower salinity (Goedecke, 1968). The inflow of the River Elbe and the great amount of rainfall in the Wadden Sea area may be influential too. The water masses collide and form a convergence zone at the contact surface. This can be seen by the vertical stratification which occurs at the stations of the mixing area. In this water body the surface water is maximally $1.3^{\circ} \mathrm{C}$ colder and of a $1.1 \%$ lower salinity than the bottom water. In the North Sea water body the surface water is maximally $0.5^{\circ} \mathrm{C}$ colder and has only a $0.5 \%$ lower salinity than the bottom water. 
The amount of micronutrients is relatively high in the Elbe estuary as well as in the Wadden Sea. This can be explained by the high input of sewage into the River Elbe comprising a relatively high portion of nutrients. On the other hand, there was a high input of nutrient-rich components into the Wadden Sea through run-off from the adjoining fields during the investigation period. The North Sea water is less affected by terrestrial influences. This water body has a nutrient and seston concentration which, if there is a difference at all, is lower than in the Elbe estuary or the Wadden Sea.

The concentration of all parameters investigated in the North Frisian coastal water and in the southern mixing area is intermediate between these two extremes. These water masses can be regarded as a mixing area. The two subareas of the mixing area differ in the concentration of important variables. Temperature and salinity are slightly but significantly higher in the southern mixing area, whereas the concentrations of $\mathrm{NH}_{4}, \mathrm{NO}_{2}$, TOC and most of the particles are lower. The amount of chlorophyll does not differ significantly. Taking chlorophyll as an indicator for the amount of phytoplankton, the observed differences in the seston concentration show that only the concentration of the detritus is higher in the North Frisian coastal water. One interpretation for this might be the influence of the north flowing Elbe water on the North Frisian coastal water.

The differences in the concentrations of the different mesozooplankton species are very small. With reference to Noctiluca miliaris and the spionid larvae distinct differences between some parts of the area investigated were observed. The same is true for Eurytemora sp. which could only be found in the Elbe estuary. The considerably higher concentrations of the gastropod larvae in the North Sea water and the southern mixing area cannot yet be explained; adult gastropods can be found throughout the North Frisian Wadden Sea in high numbers.

The analysis of the mesozooplankton revealed that eighteen different species (or developmental stages) are abundant. Only in four of eighteen cases a difference between at least two of the subareas could be found. This appears to be related to the period of research. As investigations in different areas have shown (Martens, 1976), during November breeding of the planktonic copepods ceases in temperate areas. They winter in the 5 th copepodid stage. The distribution of these crustaceans at this time is more affected by the prevailing currents than by breeding activities or other factors. As observed during this study, the currents lead from a more patchy distribution at times of high reproductive activity to a more uniform distribution.

This is not the case with larvae of Spionidae. They can be found in large numbers as late as December (Martens, 1976). During the investigation period the main occurrence of these polychaetes was recorded in areas of apparently good living conditions for the adults as well as for the larvae. Thus, their distribution does not appear to be markedly affected by the prevailing currents.

Acknowledgements. I wish to express my thanks to Dr. Weigel and Dr. Hickel (BAH) for making available data on the chemical parameters and seston components and to Mr. Becker (DHI) for data on temperature and salinity. 


\section{LITERATURE CITED}

Goedecke, E., 1968. Ober die hydrographische Struktur der Deurschen Bucht im Hinblick auf die Verschmutzung in der Konvergenzzone. Helgoländer wiss. Meeresunters. 17, 108-125.

Kalle, K., 1937. Nährstoffuntersuchungen als hydrographisches Hilfsmittel zur Unterscheidung von Wasserkörpern. Annln Hydrogr. Berl. 65, 1-48.

Künne, C., 1952. Untersuchungen über das Großplankton in der Deutschen Bucht und im Nordsylter Wattenmeer. Helgoländer wiss. Meeresunters. 4, 1-54.

Martens, P., 1976. Die planktischen Sekundär- und Tertiärproduzenten im Flachwasserökosystem der westlichen Ostsee. Kieler Meeresforsch. Sonderh. 3, 60-71.

Menzel, D. W. \& Vaccaro, R. F., 1964. The measurement of dissolved organic and particulate carbon in sea water. Limnol. Oceanogr. 9, 138-142.

Sachs, L., 1974. Angewandte Statistik. Springer, Berlin, 545 pp.

Sheldon, R. W. \& Parsons, T. R., 1967. A practical manual on the use of the Coulter Counter in marine science. Coulter Electronic Sales Company - Canada, Toronto, 66 pp. 